\title{
Research Progress on the Chemistry and Pharmacology of Prunella vulgaris Species
}

\author{
Ge Meng1 ${ }^{* \#, ~ M e i ~ W a n g 1, ~ K e j i e ~ Z h a n g ' 2, ~ Z e n g j u n ~ G u o ' ~}{ }^{1}$, Juan Shi ${ }^{*}$ \\ ${ }^{1}$ School of Pharmacy, Health Science Center, Xi'an Jiaotong University, Xi'an, China \\ ${ }^{2}$ Zhongshan Hospital, Xiamen University, Xiamen, China \\ Email: "mengge@mail.xjtu.edu.cn,
}

Received 9 April 2014; revised 13 May 2014; accepted 21 June 2014

Copyright (C) 2014 by authors and OALib.

This work is licensed under the Creative Commons Attribution International License (CC BY). http://creativecommons.org/licenses/by/4.0/

(c) (†) Open Access

\begin{abstract}
An exhaustive literature survey on the secondary metabolites of widely distributed Prunella vulgaris L. species has been carried out. Triterpenoids, sterols, phenylpropanoids, flavonoids, coumarins, fatty acids, volatile oils and carbohydrates along with some other compounds, have been reported from this species. Many of these compounds have been found to possess significant biological properties, including antihypertensive activity, anticancer activity, anti-lipidemic activity, antibacterial and antivirus activities, anti-inflammatory activities, hypoglycemic effects, heptaprotective effects, antineoplastic activities, etc. $P$. vulgaris might offer a rich natural source with relative cheap price for developing new anti-neoplastic drugs.
\end{abstract}

\section{Keywords}

Biological Properties, P. vulgaris L., Triterpenoids, Sterols, Phenylpropanoids, Flavonoid, Coumarins, Fatty Acids, Volatile Oil, Carbohydrates

Subject Areas: Medicinal Chemistry Phytochemistry

\section{Introduction}

As a commonly used Chinese native medicine, dried ears of $P$. vulgaris are used as medicine for the treatment of many kinds of disease (Figure 1). $P$. vulgaris was first literally recorded as one kind of medical grass in Volume 3 of “Shennong Bencao Jing (or Shennong's Classic of Chinese Materia Medica)” during the Qin-Han dynasty in ancient China. It was recorded as one of 365 kinds of Chinese Materia Medica. In China, this plant got its Chinese name "Xiakucao" for drying after summer solstice. In Europe, it got another name "self-heal or

\footnotetext{
*Corresponding authors.

${ }^{\#}$ Inquires about this paper are preferred to be sent to Ge Meng.
} 

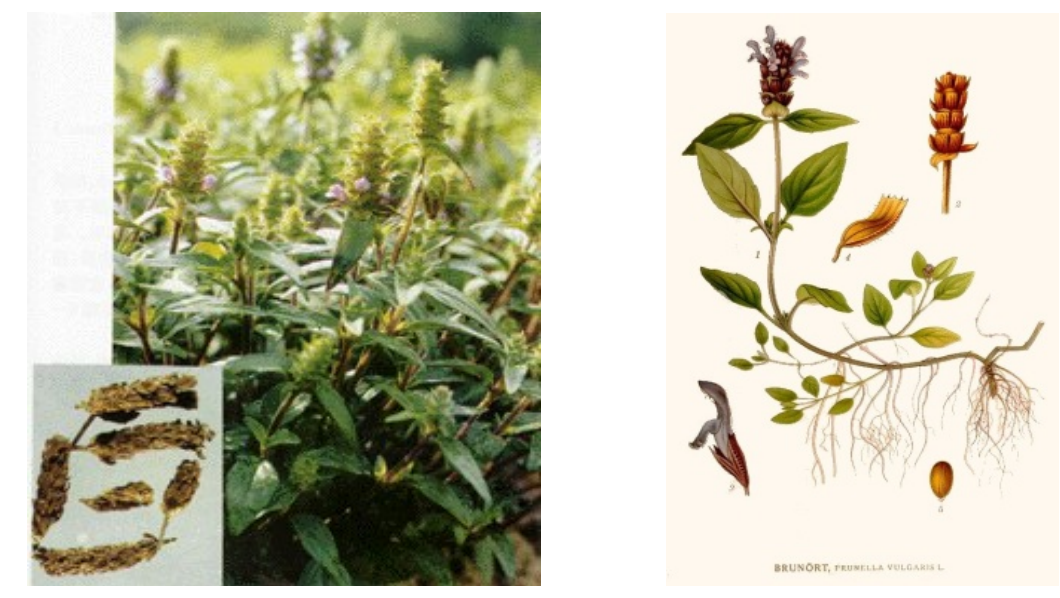

Figure 1. Pruwnella vulgaris and its matured dried ears.

self-heal spike" for its medicinal usage. The medicine made from $P$. vulgaris is also known by other names, such as Square-stem, Prunella Spike, Spica Prunellae, and Common Selfheal Fruit-Spike. P. vulgaris busts into flower during April and June and produces fruits from July to October. P. vulgaris often grows wildly on the barren mountain areas, the grasslands, the roadside and the moist ground nearby riversand other areas.

There are fifteen kinds of plant variation in the $P$. vulgaris species all over the world. They are widely distributed in places such as the warm regions of Europe and Asia, northwest region of Africa and northern region of America. Four kinds of species and three kinds of varieties are produced in China, including $P$. vulgaris and its two varieties, such as $P$. vulgaris L. var. leucantha Schur sec. Bailey and P. vulgaris L. var. lanceolata (Barton) Fernald, P. asiatica Nakai and its variations P. asiatica Nakai var. albiflora (koidz.) Nakai, P. hispida Benth and $P$. grandiflora (linn.) jacq.

$P$. vulgaris tastes bitter and has a pungent aroma. It could be absorbed by human body by going through the liver and the gallbladder organ according to Traditional Chinese Medicine. It has many medical effects such as antiinflammation, clearing vision, relief of congestion and detumescence. It is often used in the treatment of headache dizziness, swollen eyes, scrofula, cecidium, swollen and painful mastitis, breast cancer, goiter, tuberculosis [1] [2].

It has long been used as a folk medicine for alleviating sore throat and reducing fever by Europeans and Chinese. It was also used as a material to manufacture functional beverages. Modern pharmacological studies reveal that the methanol or water extracts of this herb could show many biological activities including systemic anaphylaxis inhibition, antihyperglycemic activity, UV radiation photo protection [3], immune modulation, antioxidative action, anti-viral and anti-bacterial effects [4].

As a result of its important medicinal value and widespread pharmacological action, $P$. vulgaris has received more and more attention in the world [5]. For many years, pharmaceutical scholars have conducted comprehensive research toward both chemistry and pharmacology aspects of $P$. vulgaris. In view of the medicinal properties attributed to this species, this paper presents a comprehensive review of the chemical constituents and the pharmacological activities of $P$. vulgaris.

\section{Chemical Substance}

\subsection{Triterpenoids}

There are many kinds of triterpenoid compounds existing in $P$. vulgaris, including oleanane, ursane and lupinane type triterpenoids [6] (Figure 2). The contents of ursolic acid $\mathbf{1}$ and oleanolic acid $\mathbf{2}$ in the $P$. vulgaris are much higher than those of other triterpenoids [7] [8], which are obviously correlated with the pharmacological action of the plant [9]-[11].

The activity-guided fractionation of the extract of the herb of $P$. vulgaris (Labiatae) led to the isolation of five

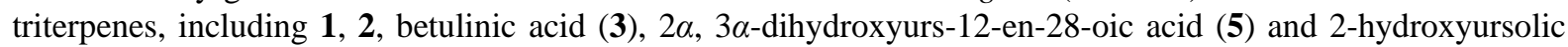
acid. Compound 5 demonstrated significant inhibition on the release of $\beta$-hexosaminidase from cultured RBL-2H3 cells in a dose-dependent manner. When the isolated compounds were tested for their effects on the production of nitric oxide from cultured murine macrophages, RAW 264.7 cells, 1 and 2-hydroxyursolic acid exhibited strong inhibitory activities (Figure 3) [12]. 


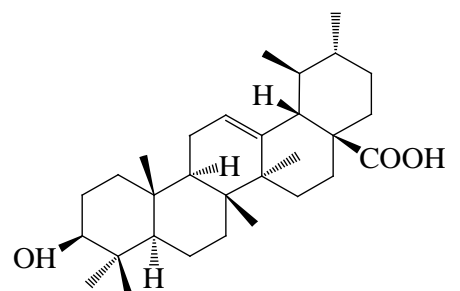

(1) Ursolic acid

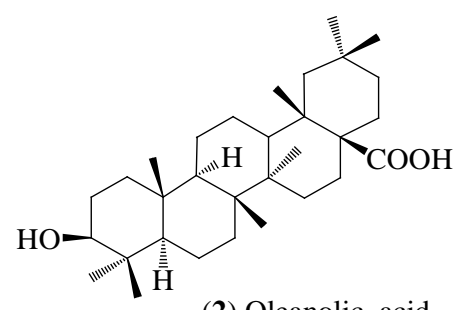

(2) Oleanolic acid

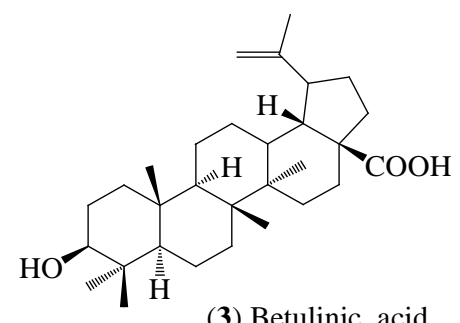

(3) Betulinic acid

Figure 2. Structures of ursolic acid, oleanolic acid and betulinic acid.

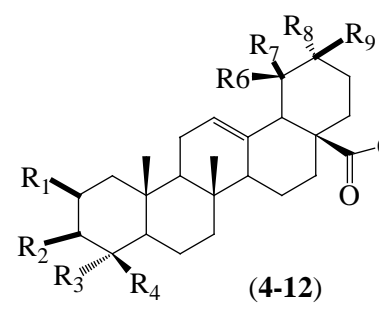

(4-12)

(4) $2 \alpha, 3 \alpha, 19 \alpha$-trihydroxyurs12en-28oic acid

$\begin{array}{lllllllll}\mathrm{R}_{1} & \mathrm{R}_{2} & \mathrm{R}_{3} & \mathrm{R}_{4} & \mathrm{R}_{5} & \mathrm{R}_{6} & \mathrm{R}_{7} & \mathrm{R}_{8} & \mathrm{R}_{9}\end{array}$

(5) $2 \alpha, 3 \alpha$-dihydroxyurs-12en- $\alpha-\mathrm{OH} \quad \alpha-\mathrm{OH} \quad \mathrm{CH}_{3} \quad \mathrm{CH}_{3} \quad \mathrm{H} \quad \mathrm{CH}_{3} \quad \mathrm{H} \quad \mathrm{CH}_{3} \quad \mathrm{H}$ 280ic acid

$\begin{array}{llllllllllll}\text { (6) Maslinic acid } & \alpha-\mathrm{OH} & \beta-\mathrm{OH} & \mathrm{CH}_{3} & \mathrm{CH}_{3} & \mathrm{H} & \mathrm{H} & \mathrm{H} & \mathrm{CH}_{3} & \mathrm{CH}_{3}\end{array}$

(7) $2 \alpha, 3 \alpha, 19 \alpha$, 23-tetrahydroxy $-\alpha-\mathrm{OH} \quad \alpha-\mathrm{OH} \quad \mathrm{CH}_{2} \mathrm{OH} \quad \mathrm{CH}_{3} \quad \mathrm{H} \quad \mathrm{CH}_{3} \quad \alpha-\mathrm{OH} \quad \mathrm{CH}_{3} \quad \mathrm{H}$ $\mathrm{OR}_{5}$ urs-12en-28oic acid

$\begin{array}{llllllllll}\text { (8) 2 } \alpha, 3 \alpha, 23-\text { trihydroxyurs- } & \alpha-\mathrm{OH} & \alpha-\mathrm{OH} & \mathrm{CH}_{2} \mathrm{OH} & \mathrm{CH}_{3} & \mathrm{H} & \mathrm{CH}_{3} & \mathrm{H} & \mathrm{CH}_{3} & \mathrm{H}\end{array}$

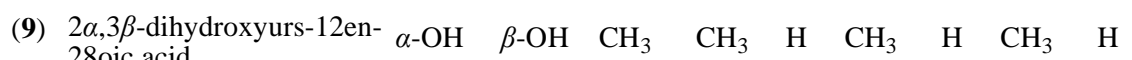

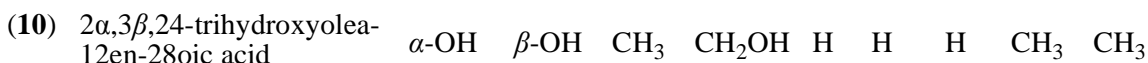

(11) $2 \alpha, 3 \alpha, 24$-trihydroxyurs-12, 20(30)-dien-28oic acid $\alpha-\mathrm{OH} \quad \alpha-\mathrm{OH} \quad \mathrm{CH}_{3} \quad \mathrm{CH}_{2} \mathrm{OH} \quad \mathrm{H} \quad \mathrm{CH}_{3} \quad \mathrm{H} \quad \mathrm{CH}_{2} \quad \mathrm{CH}_{2}$

(12) $2 \alpha, 3 \alpha, 24$-trihydroxyolea12en-28oic acid.

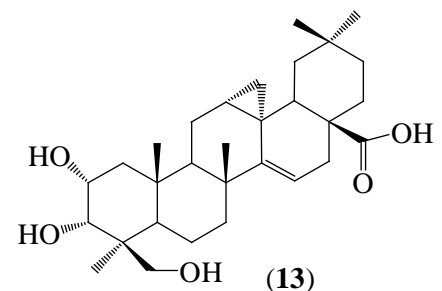

$(12 R, 13 S)-2 \alpha, 3 \alpha, 24$,trihydroxy12,13-cyclo-taraxer-14-en-28oic acid<smiles>C=C(C)C1CCC2(C(=O)OC)CCC3(C)C(=CCC4C5(C)CCC(O)C(C)(C)C5CCC43C)C12</smiles>

Methyl betulinate<smiles>COC(=O)C12CCC3C(=C1CC(C)(C)CC2)C=CC1C3(C)CCC2C(C)(CO)C(O)C(O)CC12C</smiles>

Methyl 2 $\alpha, 3 \alpha$, 24-trihydroxyl ursa-11, 13(18)-dien-28-oate
$\begin{array}{lllllll}\mathrm{CH}_{3} & \mathrm{CH}_{2} \mathrm{OH} & \mathrm{H} & \mathrm{H} & \mathrm{H} & \mathrm{CH}_{3} & \mathrm{CH}_{3}\end{array}$

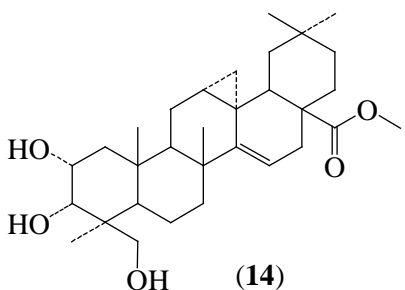

Methyl (12R,13S)-2 $\alpha$, 3 $\alpha$, 24-trihydroxyl -12, 13-cyclotaraxer-14-en-28-oate

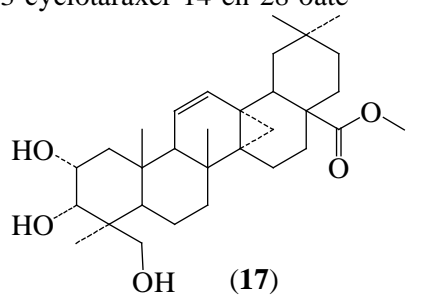

Methyl (13S,14R)-2 $\alpha, 3 \alpha$, 24-trihydroxyl -13, 14-cyclo-olean-11-en-28-oate

\section{Figure 3. Structures of triterpenes isolated from $P$. vulgaris-Part I.}

Until now, forty-two triterpenoids have been separated and identified from this species altogether, of which thirty three compounds are triterpenoid sapogenins, and eight exist in the state of saponins [13] [14]. The sugar chain of saponins are usually connected at the 28-position of the triterpenoids skeleton, few of them are connected 
in the 3-position or other position of the triterpenoid skeleton. Furthermore, the sugar chains at the 28-position are composed only of one or two monosaccharides The ${ }^{13} \mathrm{C}$ NMR spectrum for different triterpenoids shows their distinct features correlated with the skeleton type, substituted positions and configurations [6] [15] (Figure 3, Figure 4).

Pruvuloside A 33 and Pruvuloside B 34 along with triterpenoid saponins 35 - 38 have been isolated from $P$. vulgaris species grown in France (Figure 5, Figure 6), although the properties of both compounds are quite similar [16].

Other compounds were also obtained from the dried ears of $P$. vulgaris by chromatograph and identified as the following: $3 \beta, 16 \alpha$, 24-trihydroxyl-olean-12-ene-28-acid-32-O-(6-butyryl)- $\beta$-D-glucopyranose ester glucoside (Vulgar saponin B 40) (Figure 6), 2 $\alpha, 3 \alpha$-dihydroxyl-ursolic-12-ene-28-acid [17], respectively.

\subsection{Sterols}

Apart from pentacyclic triterpenoids, sterols including sitosterol 41, stigmasterol 42, spinasterol 43 and stigmast-7-en-3 $\beta$-ol $\mathbf{4 4}$ have been isolated from $P$. vulgaris and identified by Kojima. Furthermore, four $\beta$-D-glucopyranosides of the sterols have also been isolated from $P$. vulgaris and were identified by analysis of ${ }^{1} \mathrm{H} N M R$, ${ }^{13} \mathrm{C}$ NMR, HOMCOR and HETCOR spectrum [18] (Figure 7).

Eight sterols have been isolated from the ears, stem and leaves of $P$. vulgaris, of which four compounds, $\beta$-sitosterol, $\alpha$-spinasterol, stigmasterol-7-olefinic alcohol and ducosterol 46, assume a free state, another four

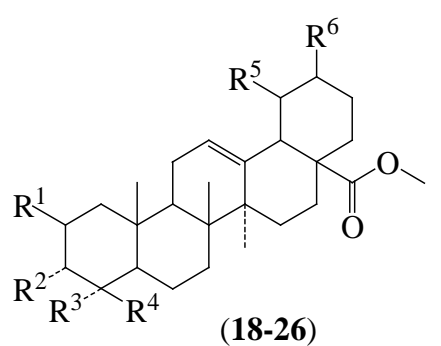

$(18-26)$

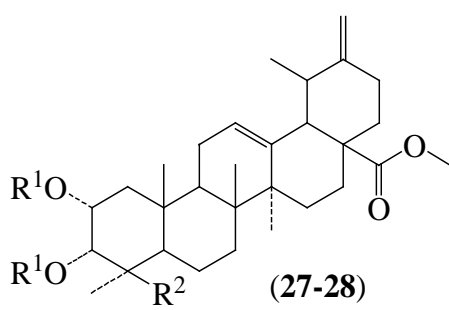

(27-28)

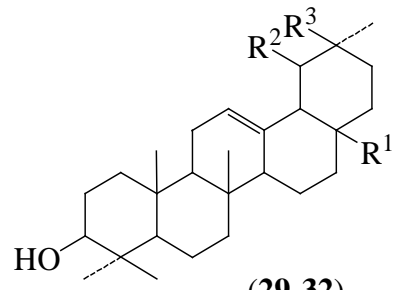

(29-32)
(18) Methyl oleanolate

(19) Methyl ursolate

(20) Methyl maslinate

(21) Methyl 3-epimaslinate

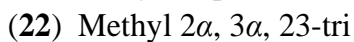
hydroxylolean-12-en-28 -oate

(23) Methyl $2 \alpha$, 3 $\alpha$, 24-tri hydro xylolean-12-en-28 -oate

(24) Methyl $2 \alpha$, $3 \alpha$, dihy droxylurs-12-en-28-oate

(25) Methyl 2 $\alpha$-hydroxy lurs-28-oate

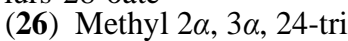
hydro xylursa-12-en-28 -oate

(27) Methyl $2 \alpha, 3 \alpha$, dihydroxylursa- 12 , 20(30)-dien-28-oate

(28) Methyl $2 \alpha, 3 \alpha, 24$ -trihydro xylursa-12, 20(30)-dien-28-oate

(29) $3 \beta$-hydroxyl-olean12-en-28-al

(30) $3 \beta$-hydroxyl-urs-12 -en-28-al

(31) Olean-12-en-3 $\beta$, 28-diol

(32) Urs-12-en-3 $\beta$, 28-diol
$\mathrm{R}$

$\mathrm{R}^{1} \quad \mathrm{R}^{2}$

$\mathrm{H} \quad \beta-\mathrm{OH}$

$\mathrm{R}^{3}$

$\mathrm{R}^{4}$

$\mathrm{R}^{5} \quad \mathrm{R}^{6}$

$\mathrm{H} \quad \beta-\mathrm{OH}$

$\mathrm{Me}$

$\mathrm{Me}$

$\mathrm{H} \quad \mathrm{Me}$

$\mathrm{OH} \quad \beta-\mathrm{OH}$

Me

$\mathrm{Me}$

$\mathrm{Me} \quad \mathrm{H}$

$\mathrm{OH} \quad \alpha-\mathrm{OH}$

Me

Me

$\mathrm{H} \quad \mathrm{Me}$
$\mathrm{OH} \quad \alpha-\mathrm{OH}$
H

OH

$\mathrm{OH}$

$\alpha-\mathrm{OH}$

Me

Me

H

Me

$\mathrm{OH} \quad \alpha-\mathrm{OH}$

$\mathrm{OH} \quad \beta-\mathrm{OH}$

$\mathrm{CH}_{2} \mathrm{OH} \quad \mathrm{Me}$

$\mathrm{H}$

Me

$\mathrm{OH} \quad \beta-\mathrm{OH}$

Me

Me

Me

H
$\mathrm{H} \quad \mathrm{CH}_{2} \mathrm{OH}$

$\mathrm{CHO} \quad \mathrm{H} \quad \mathrm{Me}$

$\mathrm{CHO} \quad \mathrm{Me} \quad \mathrm{H}$

$\mathrm{OH} \quad \mathrm{H} \quad \mathrm{Me}$

$\mathrm{OH} \quad \mathrm{Me} \quad \mathrm{H}$ 


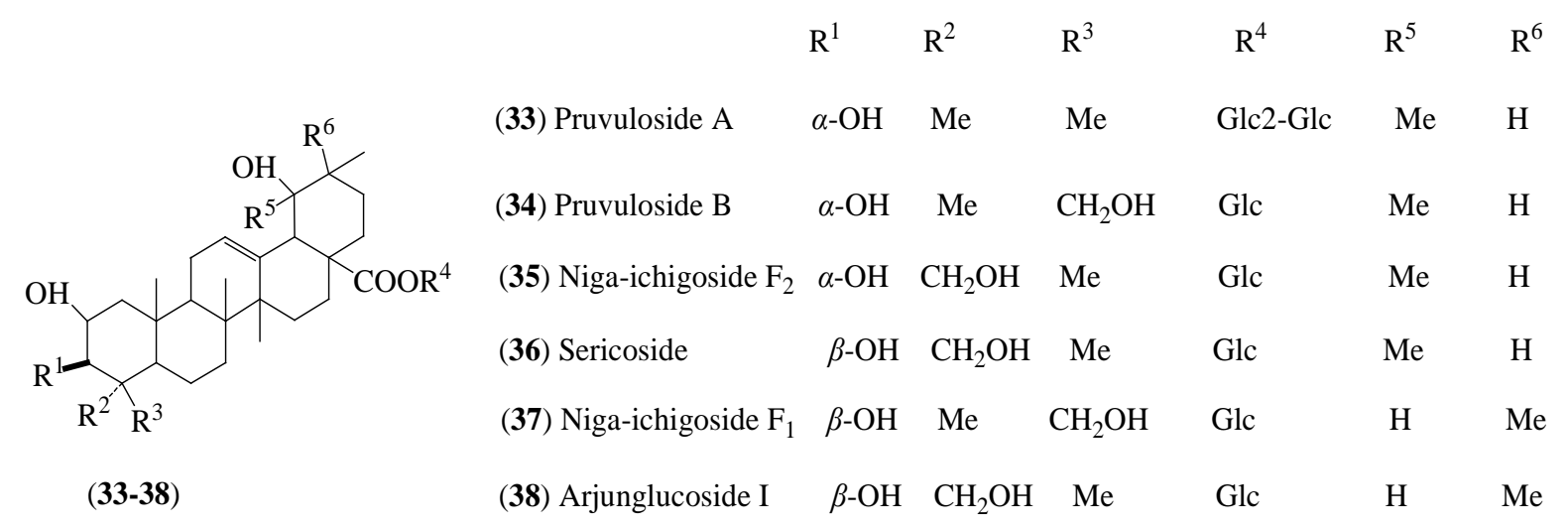

Figure 5. Structure of the triterpenoid saponins from $P$. vulgaris.<smiles>CC1(C)CCC2(C(=O)OC3OC(CO)C(O)C3O)CCC3(C)C(=CCC4C5(C)CC(O)[C@@H](O)C(C)(CO)C5CCC43C)C2C1</smiles>

(39) Vulgar saponin A

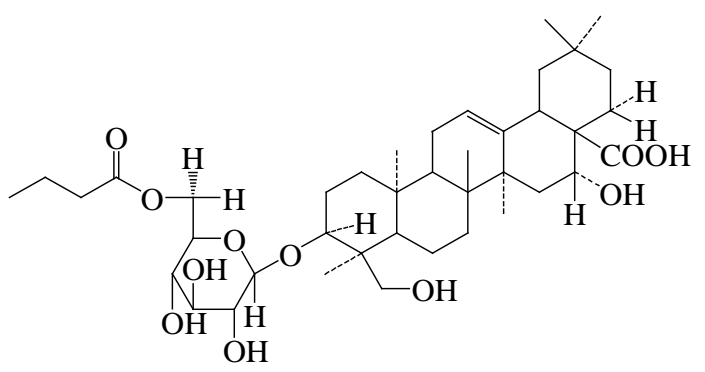

(40) Vulgar saponin B

Figure 6. Structure of Vulgar saponin A and Vulgar saponin B.

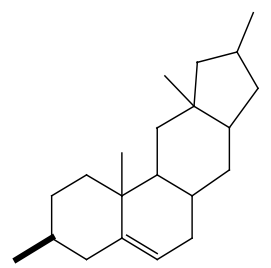

skeleton 1<smiles>CCC(C)CCC(C)(CC)C(C)C</smiles>

$\mathrm{R}^{2} \mathrm{a}$

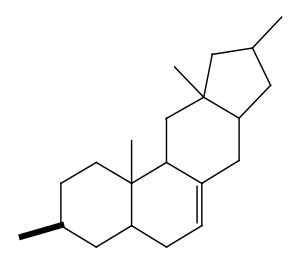

skeleton 2

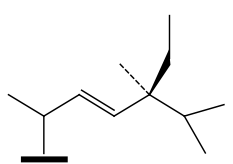

$\mathrm{R}^{2} \mathrm{~b}$
(41) Sitoserol

(42) Stigmasterol

(43) Spinasterol

(44) Stigmast-7-en-3 $\beta$-ol

(45) $(22 E, 20 S, 24 S)$-stigmasta

-7,22-dien-3-one

(46) Daucosteol =O
$\mathrm{R}^{1}$

skeleton $+\mathrm{R}^{2}$

$\alpha-\mathrm{OH}$

$1 \mathrm{a}$

$\alpha-\mathrm{OH}$

$1 \mathrm{~b}$

$\alpha-\mathrm{OH} \quad 2 \mathrm{~b}$

$\beta-\mathrm{OH} \quad 2 \mathrm{a}$

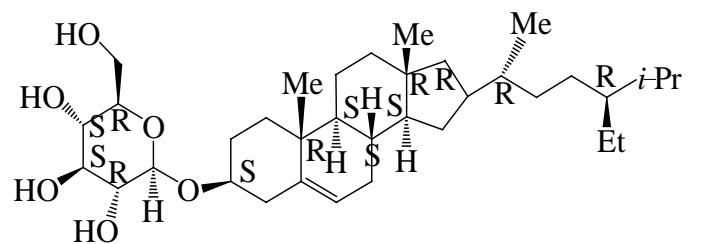

(47) $\beta$-D-glucopyranosides

Figure 7. Structure of steroids from $P$. vulgaris L. 
are the glucose glucosides, such as $\alpha$-spinasterolyl- $\beta$-D-glucopyranose glucoside, stigmasterolyl- $\beta$-D-glucopyranose glucoside, stigmast-7-enyl- $\beta$-D-gluco-pyranoside 44 and (22E, 20S, 24S)-stigmasta-7,22-diene-3-one 45 [19].

Anti-neoplastic cyasterone has been isolated from P. vulgaris L. var. leucantha Schur sec. Bailey. The content of cyasterone in $P$. vulgaris was also determined at the same time [20].

Six compounds have been isolated from the ears of $P$. vulgaris by modern chromatography methods. These sterols are $\beta$-amyrin 49 (Viminalol) (Figure 8), $\alpha$-spinasterol, stigmasterol, stigmasterol-7-ene-23 $\beta$-ol and $2 \alpha, 3 \alpha$, 24-trihydroxyl-olean-12-ene-28-acid-28- $\beta$ - $D$-glucopyranose ester glucoside (Vulgar saponin A 39) (Figure 6) [21]. Cholesterol was also found in this plant.

\subsection{Phenylpropanoids}

The antioxidant potential of $P$. vulgaris was found in vitro and in vivo and is probably associated with phenolic acid content, mainly rosmarinic acid (RA) 51 (Figure 9), which is known for its wide ranging antioxidative, anti-inflammatory, antimutagenic, antibacterial, antiviral and immunosuppressive biological activities [22].

Apart from phenolic acids such as $P$-cumaric acid 50, rosmarinic acid $\mathbf{5 1}$ cis-caffeic acid and trans-caffeic acid 52, several other compounds have also been separated from $P$. vulgaris by Chinese researchers, such as methyl rosmarine, ethyl rosmarine, E-butyl rosmarine, Z-butyl rosmarine, ethyl caffeate, 3, $4 \alpha$-trihydroxyl -methyl-phenyl propionate, 3,4 $\alpha$-trihydroxyl-butyl-phenyl propionate [23], Danshensu 53 and it’s ethyl acetate 3,4-dihydroxyphenyl lactate [13] (Figure 9).

Quercetin and quercetin-3-O- $\beta$-D-galactoside were also obtained from the dried ears of $P$. vulgaris by chromatograph [17].

\subsection{Flavonoids}

Seventeen flavonoids have been isolated and identified from $P$. vulgaris, including 5-hydroxyl flavanone, luteolin 54, kaemferol, kaemferol-3-O-glucoside 60, rutin 61 [24], isoquercitrin, 5-hydroxyl flavanone-3-O-galactoside, anthocyanins, delphinidin, hirsutidin-3,5-diglucoside, malvidin-3,5-diglucoside, hyperin, luteoloside, peonidin-3,5-diglucoside [25], homoorientin 55, cinaroside 56, quercetin 57, quercetin-3-O- $\beta$-D-galactoside 58 and quecertin-3-O- $\beta$-D-glucoside 59 [26].

Beside the above compounds, $P$. vulgaris also contained flavonoid glycosides (galactoside), such as hyperoside(2-(3,4-dihydroxyphenyl)-3-( $\beta$-D-galactopyranosyloxy)-5,7-dihydroxy-4H-1-benzo-pyran-4-one) (Figure 10) and acacetin-7-O- $\beta$-D-gluco pyranoside [14].

Anthocyanidins, such as delphinidin 62 and cyanidin 63, also existed in the blossom clusters of $P$. vulgaris (Figure 11). As the flavonoid analogues, anthocyanidin is one kind of chromene derivatives usually existing in the ion form.

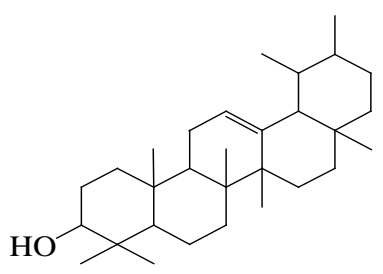

(48) a-amyrin

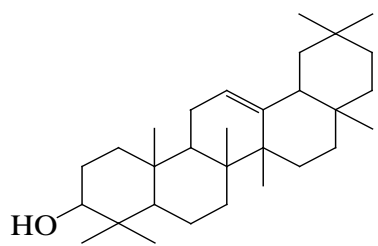

(49) $\beta$-amyrin

Figure 8. Structure of $\alpha$-amyrin and $\beta$-amyrin.<smiles>O=C(O)C=Cc1ccc(O)cc1</smiles>

(50) P-Coumaric acid

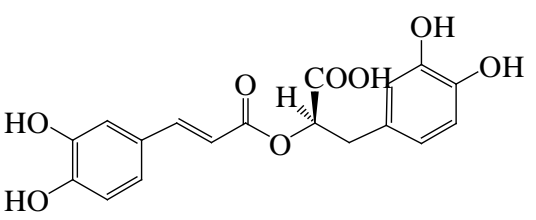

(51) Rosmarinic acid<smiles>O=C(O)C=Cc1ccc(O)c(O)c1</smiles>

(52) Caffeic acid<smiles>O=C(O)C(O)c1ccc(O)c(O)c1</smiles>

(53) Danshensu

Figure 9. Structure of P-coumaric acid, rosemary acid, caffeic acid and danshensu. 


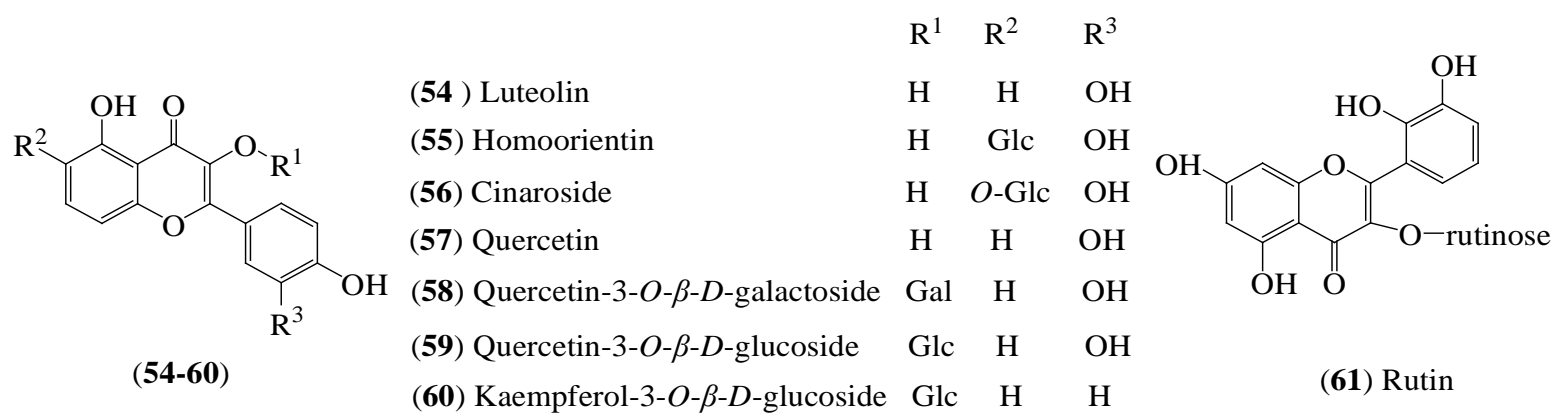

Figure 10. Structure of flavonoids in P. vulgaris.<smiles></smiles>

(62) Delphinidin $\mathrm{R}^{1}=\mathrm{R}^{2}=\mathrm{OH}$

(63) Cyanidin $\quad \mathrm{R}^{1}=\mathrm{OH}, \mathrm{R}^{2}=\mathrm{H}$

Figure 11. Structure of delphinidin and cyaniding.

The structural feature of most of these compounds, including flavonoids, flavonols, anthocyanins and their glycosides, is that the sugar groups are often attached at the 3-position of the main skeleton. Ethyl coffee acid ester was also isolated and identified from the dried ears of $P$. vulgaris [17].

\subsection{Coumarins}

Until recently, only three coumarins have been isolated from $P$. vulgaris by Russian scholars Dmitruk. Umbelliferone 64 [24], scopoletin 65 and esculetin 66 [24] have been identified by both spectral analysis and chemical and physical properties [27] (Figure 12).

\subsection{Fatty Acids}

Fatty acids are carboxylic acids often with a long unbranched aliphatic chain, which is either saturated or unsaturated. The fatty acids in $P$. vulgaris are isolated and reported as oleic acid, linoleic acid, lauric acid, palmitic acid (cetylic acid), myristic acid, stearic acid and tetracosanoic acid. Beside, another five fatty acid derivatives have been identified as ethyl palmitate, 6,9-octodecadienoic acid, 3,6,7-eicosatrienoic acid, archidic acid and behemic acid with GC-MS [21].

\subsection{Volatile Oils}

The studies on volatile ingredients in $P$. vulgaris showed that the volatile oil has been obtained at a rate of 0.31\%. By using GC-FT-IR methods, twenty three known components have been isolated from P. vulgaris. The principal constituents are 1,8-eucalyptol, $\beta$-pinene, myrcene, linalylacetate 67, $\alpha$-phellandrene 68 and linalool 69 (Figure 13). The content of 1, 8-eucalyptol and $\beta$-pinene constitutes more than $60 \%$ of the total volatile oil [28].

Another fourteen compounds have also been identified in the ears $P$. vulgaris by Wang, the content of the main constituents, such as 1,6-cyclodecanone-diene, hexadecanoic acid and hexatriacontane are $17.16 \%, 10.94 \%$ and $4.04 \%$ respectively [29].

The results of contents of volatile oil are different, which may be related with the different parts dryness and collecting period of $P$. vulgaris. 
<smiles>[R]c1cc2ccc(=O)oc2cc1O</smiles>

(64) Umbelliferone, $\mathrm{R}=\mathrm{H}$;

(65) Scopoletin, $\mathrm{R}=\mathrm{OMe}$;

(66) Esculetin, $\quad \mathrm{R}=\mathrm{OH}$.

Figure 12. Structure of umbelliferone, scopoletin and esculetin.<smiles>C=CC(C)(CCCC(C)C)OC(C)=O</smiles>

(67) Linalyl acetate<smiles>CC1=CCC(C(C)C)C=C1</smiles>

(68) $\alpha$-Phellandrene<smiles>C=CC(C)(O)CCC=C(C)C</smiles>

(69) Linalool

Figure 13. Active components in volatile oils.

\subsection{Carbohydrates}

$P$. vulgaris contains dissoluble monosaccharides, disaccharides and polysaccharides. Dissociated glucose, galactose, fructose and sucrose have also been isolated and obtained from P. vulgaris [30]. A sulfur-containing polysaccharide (Prunellin) has also been isolated from the water soluble extraction of $P$. vulgaris, the molecular weight of which has been identified to be around 10,000 [31].

Sucrose, mannose, glucose and fructose have been detected from the ethanol extract of $P$. vulgaris, $P$. vulgaris L. var. leucantha Schur sec. Bailey. The glycosides of mannose, glucose, arabinose, xylose and rhamnose have also been obtained from both water and ethanol extractions of these above two speices. Fructose was also found in P. vulgaris L. var. lanceolata (Barton) [32].

DEAE-Sepharose FF chromatography was used by Chinese scholars to purify polysaccharides from $P$. vulgaris L. Their structures were characterized through chemical and spectral methods. Five polysaccharides were obtained from the water extract and three which were named XKC00, XKC02-A and XKC02-B were homogeneous, molecular weights estimated by HPGPC to be $26,000,136,000,5600$. XKC00 is a neutral heteropolysaccharide obtained for the first time from this herb [33].

\subsection{Other Components}

Vitamin A, vitamin C, vitamin K, vitamin B1, vitamin PP (niacin), carotene, daucosterol, bicylic monoterpenoids ( $d$-camphor, $d$-fenchone), tannic acid, resin, bitter substance, fatty oil, alkaloid (1120 mg\%), proteins (441.6 $\mathrm{mg} \%$ ) and lipids (2403.8 $\mathrm{mg} \%$ ) are contained in P. vulgaris. Apart from these above compounds, P. vulgaris also contains $3.5 \%$ water-soluble inorganic salts, in which potassium chloride constitutes $68 \%$ [34].

\section{Biological Activities}

\subsection{Antihypertensive Activity}

Clinical treatments of hypertension with the compound preparations from $P$. vulgaris have achieved good results [35] [36]. Pharmacology experiments have proved that both water extract and ethanol-water (30\%) extract from $P$. vulgaris could reduce the blood pressures of anesthetic animals. The stems, leaves, ears and whole grass of $P$. vulgaris have antihypertensive effects, while the function of the ears is relatively less than that of other parts. Potassium salts in $P$. vulgaris have been suggested to be the active ingredients for antihypertensive activity. Biological activity screening had shown that both methylene chloride extract and methanol extract show activity against $\alpha$-adrenalin receptor, dopamine receptor, cephatide receptor, enkephalin receptor and diazepam receptor. The principal constituents $\mathbf{1}$ and $\mathbf{2}$ have been isolated from the methylene chloride extract of $P$. vulgaris. The total saponins, in which both $\mathbf{1}$ and $\mathbf{2}$ are constituted as the main sapogenins, have also been separated from the methanol extract of $P$. vulgaris. The pharmacological experiment had shown that both the sapogenins $(\mathbf{1}, \mathbf{2})$ and 
their total saponins have antihypertensive activity [37].

The antihypertensive activities of Sancaojiangyatang, which has been prepared from P. vulgaris, Leonurus siribicus and Rough gentian, have been studied on normal domestic rabbits, Wislar rats and acute experimental renal hypertension rats (RHR). This compound preparation showed positive antihypertensive activity on normal domestic rabbits and displayed a positive quantity-activity relationship $(\mathrm{P}<0.01)$. The antihypertensive activities have remarkable statistical significance $(\mathrm{P}<0.01)$ by comparing the changes of blood pressures of Wislar rat before and after using this preparation. This prescription could obviously suppress the increase of blood pressure of RHR with statistical significance $(\mathrm{P}<0.05$ or $\mathrm{P}<0.01$ ) using physiological saline as the control group. Other reports also had shown that $P$. vulgaris could assume double functions on blood pressure, which means that a small amount of decoction has the expansion function on blood vessels, while a large amount has the weak expansion affects, and even may have vasoconstriction effects instead [38]. Total saponins from $P$. vulgaris (PVS) have been isolated and obtained by Wang. The diastolic blood pressure and the systolic blood pressure of the anesthetic rat could be decreased by using a dosage of $2.5 \mathrm{mg} / \mathrm{kg}$ of PVS. There are relationships between the diastolic/systolic blood pressures and the logarithm of the dosage of PVS [39].

The antihypertensive activity on spontaneous hypertensive rat (SHR) of Sanwujiangyatang prepared from $P$. vulgaris leucantha schur sec. bailey, Cassia tora Linn. and toasted Eucommia ulmoides, as well as the effects on the killing cells (LAK cells) activated by the lymph factors have been observed by Feng et al. [40]. The positive antihypertensive activity of this preparation had shown with statistical significance $(\mathrm{P}<0.05)$ based on the blood pressures before and after dosing SHR rats. While contrasting with physiological saline control group, the results were also statistical significant $(\mathrm{P}<0.05)$. After being treated with Sanwujiangyatang, the systolic pressures of patients were decreased significantly, while the multiplication and the vitality of LAK cells, radicaleliminating effects and the expression quantity of super oxidase (SOD)-like substances were increased significantly. The correlation between the increasing pressures and the decreasing SOD are remarkable [40].

Thoracic aortic rings of rats cultivated by the LAK cells (from the spontaneous hypertensive rats being treated with Sanwujiangyatang) have been increased to some extent by the diastolic function of acetylcholine. Recent studies have shown that the reasons for the significant decreasing of endothelium-dependent vasodilatation effects might not be due to the damages of any links in the L-arginine/nitrogen monoxide pathway and not due to the defects in M-acceptors on the endothelial cells [41], but due to the inactivation of nitrogen monoxide by excessive superoxide anion free radicals owing to the decreasing of the SOD in hypertensive patients [42]. Sanwujiangyatang could increase the SOD-like substances so significantly that blood pressures of the patients could be reduced, which have indicated that Sanwujiangyatang could offer the new effective ways for both treatment of hypertensions and regulation of immune functionality.

\subsection{Promoting Blood Circulation and Removing Blood Stasis}

By injecting adrenalin to the white rats subjected to an ice-bath, Chen had created the acute blood stasis model of stagnation of cold and qi. The effects of $P$. vulgaris on the prothrombin time (PT), the blood plasma euglobulin lysis time (ELT) and the hemorheology of the model rats had been observed and researched. The results had indicated that $P$. vulgaris could obviously extend PT of model rats, reduce ELT $(\mathrm{P}<0.01,0.05)$ and improve some of the indexes of the hemorheology. Based on these results, $P$. vulgaris is thought to have the activities of anticoagulation and enhancement of fibrinolytic function [43].

Taking $P$. vulgaris as the main medicine, Liu had prepared capsules from P. vulgaris, Fritillaria thunbergii Miq., Dioscorea bulbifera L, Draconis Resina, Salivae Miltiorrhizae Radix, Carapax trionycis, Semen coicis and others [44]. This preparation, with the effects of activating the blood circulation, reducing phlegm, softening and resolving hard mass, was used for the treatment of the experimental endometriosis model of domestic rabbits. The results showed that the whole blood viscosity, the blood plasma viscosity, the blood cells pressure, the erythrocyte sedimentation rate and the weight of implantation could be decreased significantly compared with the control group.

The results of histopathology observation had also shown that the implanted endometriosis tissues might show signs of atrophy, which indicated that the abnormal hemorheology of domestic rabbits could be improved significantly and the abnormal proliferation of endometriosis could also be inhibited. It should be noted that $P$. vulgaris has the function of improving blood circulation and removing blood stasis, as well as the action of softening and resolving hard mass. Clinical reports have also shown that $P$. vulgaris compound prescription could 
be used to treat the ischemic vascular disease [45].

The total P. vulgaris saponins (PVS) have been extracted from $P$. vulgaris. Four hours after ligation on the coronary artery and then being injected with $20 \mathrm{mg} / \mathrm{kg}$ of PVS into the abdominal cavity, the myocardial infarction scope of the anesthetic rats could be shrunken, compared with the control group. The results showed that $P$. vulgaris extraction could expand the heart coronary artery by activating blood circulation [39].

\subsection{Antilipidemic Activity}

The observation of the influential effect on the metabolism of blood lipids of Sian capsules ( $P$. vulgaris, Hirudo nipponia Whitman, Coptidis Rhizoma and so on) has shown that Sian capsules could adjust the proportion of blood lipids of many kinds of animals by decreasing the indexes of TG, VLDL and blood lipid (P $<0.05$ or $\mathrm{P}<$ 0.01), obviously decreasing the level of TCH, LDL and APOB of diabetic model rabbits ( $\mathrm{P}<0.05$ or $\mathrm{P}<0.01)$, increasing the level of HDL in young white rats $(\mathrm{P}<0.05)$ and decreasing the level of ox LDL and LPa of atherosclerosis model rabbits [46].

\subsection{Antibacterial and Antivirus Activities}

P. vulgaris shows a good antimicrobial effect to influenza, streptococcus, Kata bacteria, Staphylococcus aureus, Pneumococcus, Pseudomonas aeruginosa and Escherichia. coli. The water decoctum of $P$. vulgaris has a broad spectrum of antibacterial activities. In vitro experiments indicated that $P$. vulgaris decoctum had strong inhibitory activity against Gram-negative bacilli, such as Dysentery bacillus, Typhoid bacillus, Paratyphoid bacillus, Cholera vi-brio, E. coli, Pseudomonas aeruginosa, Proteus, Yersinia pestis, Bacillus anth, and Gram-positive bacilli, such as $\alpha$ - or $\beta$-Hemolytic streptococcus, Diphtheria bacteria, Streptococcus pneumoniae, and Human-type Mycobacterium tuberculosis (H37) [47]. The water decoctum (1:4) showed inhibitory action at different level on Leather Ashland's rubrum, Odua Ang's small Bacillus yellow rubrum and other pathogenic dermal fungi in vitro [48]. $P$. vulgaris could alleviate symptoms of the lungs of mouse with experimental tuberculosis [1].

A sulfur containing polysaccharide (prunellin) isolated from $P$. vulgaris showed inhibitory action on Human Immunodeficiency Virus (HIV) [48]. The crude extract from $P$. vulgaris could obviously suppress HIV with low cell toxicity. Zheng has researched on the anti-herpes simplex virus (HSV) type I effects of $P$. vulgaris extract using human embryonic skin muscle monolayer cell culture technology, demonstrating the obvious anti-viral activity of $P$. vulgaris extraction [49] [50]. The observation on the anti-inflammatory and analgesic effects of the oral liquid and paste from $P$. vulgaris had shown that the oral liquid from $P$. vulgaris could obviously inhibit mouse ear edema induced by croton oil, reduce the increasing permeability of the capillary vessel caused by aceic acid, inhibit both paw oedema and granulation hyperplasia of rats induced by carrageenan or egg white, and show the effective analgesic function against pain caused by acetic acid [51] [52]. The sensitivity test against resistant Staphylococcus aureus by the cylinder-plate method showed that $P$. vulgaris had better activity against the resistant Staphylococcus aureus than vancomycin hydrochloride [53]. Inhibition of the monkey immuno-deficiency virus in vitro by the Chinese native medicine compound prescription Aikeqing (containing Viola philippica Car, P. vulgaris, Scutellariae baicalensis and Salvia Miltrorrhiza) was observed [54] and showed that the inhibition rate on antigen-cells by Aikeqing is $69.6 \%$ at sub-cytotoxic concentration (1:32) with the remarkable decreasing in viral duplication. The inhibition percentage of the SIV $-{ }^{1}{ }^{27}$ antigen expression was 94.67\%, showing the similar curative effect to AZT, which is an efficient anti-HIV-1 agent.

The polysaccharides isolated from $P$. vulgaris have marked immune-stimulatory effects, which may bring about the anti-microbial effects [55] and has specific activity against HSV [49]. The mode of action appears to be different from other anionic carbohydrates, such as heparin [56]. The aqueous and methanol extractions of $P$. vulgaris used as anti-fever remedies in China were screened for their in vitro inhibition on human immunodeficiency virus type-1 protease (HIV-1 PR) [57]. It has been reported that extracts of the spike of $P$. vulgaris exhibit anti-HIV activity at the adsorption and reverse transcription stages [58]. The anti-HIV-1 activity of aromatic herbs in Labiatae was evaluated in vitro, $P$. vulgaris aqueous extracts inhibited giant cell formation in co-culture of Molt-4 cells with and without HIV-1 infection and showed inhibitory activity against HIV-1 reverse transcriptase (RT) [59] [60]. Prunellin, an anti-HIV compound isolated from aqueous extractions of $P$. vulgaris, is a partially sulfated polysaccharide with the molecular weight of approximately 10,000.

The aqueous and methanol extracts of $P$. vulgaris have also shown anti-HIV-1 integrase activity in a non-radioactive ELISA-based HIV-1 integrase (IN) assay [61]. With the aid of the ELISA system this schema 
represented a laboratory approach to the recognition of anti-HBsAg capability by using $P$. vulgaris herbal extracts [62].

\subsection{Anti-Inflammatory Activities}

P. vulgaris has been used therapeutically for inflammation-related conditions for centuries, but systematic studies of its anti-inflammatory activity are lacking and no specific active components have been identified. Recently, extracts from different accessions of $P$. vulgaris were screened for anti-inflammatory activity to identify accessions with the greatest activity. Recently, the antihyperglycemic activity of $P$. vulgaris L. in streptozotocin-induced diabetic mice has been reported [63]. Rosmarinic acid (RA) content in P. vulgaris was found to independently inhibit inflammatory response, but it only partially explained the extract's activity. LPS-induced cyclooxygenase-2 (COX-2) and nitric oxide synthase ( $i$-NOS) protein expression were both attenuated by $P$. vulgaris ethanol extract, whereas RA inhibited only COX-2 expression [64] [65] had tested the effects of $P$. vulgaris L. extract and its component rosmarinic acid on LPS-induced oxidative damage and inflammation in human gingival fibroblasts. PVE and RA reduced reactive oxygen species (ROS) production, intracellular glutathione (GSH) depletion as well as lipid peroxidation in LPS-treated cells. The results indicated that PVE and RA were able to suppress LPS-induced biological changes in gingival fibroblasts. The effects of PVE and RA are presumably linked to their anti-inflammatory activities and thus use of PVE and RA may be relevant in modulating the inflammation process and including periodontal disease.

SKI 306X is a purified extract from a mixture of three oriental herbal medicines (Clematis mandshurica, Trichosanthes kirilowii and P. vulgaris) that have been widely used for the treatment of inflammatory diseases such as lymphadenitis and arthritis in Far East Asia [66]. Protective effects of SKI 306X, on articular cartilage was examined and compared with other osteoarthritis (OA) drugs using in vitro and in vivo models. This strongly suggests that SKI 306X can be a good OA agent with some cartilage protection activity [67].

Hypodermic injection with $P$. vulgaris inoculation fluid might obviously cause the atrophy of the thymus and the spleens of experimental animals, an increase of the adrenal gland and an increase of blood plasma cortisol level after the abdominal cavity admininistration [68], which indicated that $P$. vulgaris might act as a possible immunity inhibitor in the latent treatment of pathology damage caused by the immunity process. The results of animal experimentation indicated that $P$. vulgaris could show remarkable inhibitory activity on the early inflammatory reaction, which might be closely related to the synthesis and the enhancing of secretion of the sugar cortical hormone in adrenal cortex glucocorticoid. As for the effect on the immune organs, $P$. vulgaris could inhibit both the non-specific immune function of the inflammatory response and specific immune functions [69] [70].

\subsection{Hypoglycemic Effect}

$50 \mathrm{mg} / \mathrm{kg}$ dosage of the effective component of $P$. vulgaris (hypoglycemic hormone) could obviously suppress elevated blood glucose in mice caused by alloxan, with the effect of $100 \mathrm{mg}$ of hypoglycemic hormone being equal to that of $22.6 \mu \mathrm{g}$ of insulin. The lowest effective dose without toxicity is $15 \mathrm{mg} / \mathrm{kg}$ [71]. The level of the blood glucose level of the normal mouse and the diabetes model mouse induced by alloxan could be reduced by being treated with the alcohol extract from $P$. vulgaris $(0.5 \mathrm{~g} / \mathrm{kg}$. IP). Treatment with this extract $(0.5-0.25 \mathrm{~g} / \mathrm{kg}$ $\times 3 d$. IP) could inhibit elevated blood glucose by andrenaline, improve glucose tolerance, and increase the synthesis of hepatic glycogen. The mechanism might be connected with the ability to repair the $\beta$-cells, normalize the secretion of insulin, or increase the conversion and utilization of glucose in vivo, which had been verified by clinical cases [72]. The alcoholic extract of $P$. vulgaris (AEP) was found to prevent and control renal diseases of experimental diabetic rats by obviously reducing urinary protein in diabetic rats. 100mg/kg of AEP could be used to reduce the concentrations of serum urea nitrogen and creatinine. The mechanism might be reducing the loss of inositol and the accumulation of sorbitol caused by sustaining high-sugar levels and maintaining the normal physiological function of cells and tissues by inhibiting the activity of kidney aldose reductase (AR), which might be the synergetic effect of these basic chemical constituents, including triterpenoid glycosides, flavonoids and coumarins [73].

\subsection{Effect of Protecting the Hepatobiliary System}

The result of animal experiments indicated that $P$. vulgaris mixture (P. vulgaris, Scutellaria baicalensis, Artemisia 
capillaries, etc.) could obviously protect against chemical-induced liver injury caused by $\mathrm{CCl}_{4}$, D-galactosamine and lipopolysaccharide (LPS) and immunological liver injury caused by Bacillus Calmette-guerin (BCG) vaccine and LPS [74]. The compound prescription of $P$. vulgaris could significantly decrease the fibrosis indexes including the procollagen type-IV, the hyaluric acid and the laminin $(\mathrm{P}<0.01)$. The treatment effects with $P$. vulgaris were obviously better than the treatment without $P$. vulgaris on the latter two indexes, such as the hyaluric acid and the laminin [75]. The mechanism of the anti-fibrosis activity of $P$. vulgaris is worthwhile to be researched furthermore.

\subsection{Antineoplastic Activities}

$P$. vulgaris has been used in the treatment of malignant cancer for many years [76]. The anti-colon cancer activity of $P$. vulgaris was reported recently by Liu [77]. Pharmacological research had indicated that the water extract, the water-soluble portion of ethanol extract and the residue obtained after extraction from $P$. vulgaris could inhibit U 14 tumor in mice with the rate of $42.2 \%, 34.1 \%$ and $36.2 \%$, respectively. Water extract from $P$. vulgaris could inhibit both sarcoma-180 $\left(\mathrm{S}_{180}\right)$ in mice with a rate of $5.5 \%$ and Ehrlich's ascites carcinoma in mice. Experimental research on the apoptosis of cancer cells in vitro indicated that $P$. vulgaris could induce the apoptosis of SGC-7910 cancer cells and block the cell cycle between the G1 and G2 [78]. The experiment on the anti-tumor in vivo also showed that ursolic acid and its derivatives in $P$. vulgaris might show remarkable cytotoxic activity on P388, L1210 and human lung tumor cells A-549 [79]. By injecting rabbits with P. vulgaris with hydrothorax, Xu observed that the pleural surfaces of the experimental rabbits were rough, reddish and congested with adhesive tendency, which was verified by microscopic examination showing the obvious fibrotic thickening between the splanchnic layer pleurae in the thoracic cavity of the experimental rabbits adhered by large amount of lymphocytes. The result demonstrated that $\mathrm{P}$. vulgaris injection could not only show significant anti-neoplastic activity but also promote fibrotic overgrowth, which resulted in the theraputic adhesion of pleurae [80]. P. vulgaris injection was used in the treatment of 78 cases of patients with bronchitic lung cancer by intrapleural injections, with more effective treatment results $(\mathrm{P}<0.01)$ and less side-effects $(\mathrm{P}<0.05)$ than both $\beta$-elemene and cis-platin/VP16 in chemotherapy group [81].

Studies of apoptosis of cancer cells in vivo and in vitro indicated that $P$. vulgaris $\mathrm{L}$ could induce apoptosis of EL-4 cells by researching on the proliferation of the Jurkat human lymphoma cell line [82]. The effective parts of $P$. vulgaris could significantly inhibit the proliferation of Raji cells, Jurkat cells K562 cells and 4355 cells in vitro. P. vulgaris could inhibit Dutch T lymphoma EL-4 cells in mice in vivo by prolonging the survival period with positive anti-tumor effects and relatively lower toxicity [83]. P. vulgaris contains anti-mutagenic factors against both picrolonic acid and benzo[ $\alpha$ ]pyrene-induced mutation [84]. P. vulgaris have also shown significant antioxidative activities, by free radical scavenger effect on DPPH, compared with those of Rosmarinus officinalis L. and Salvia officinalis L. extracts [85].

Although there are many chemical compositions in P. vulgaris, it is still not very clear which ingredient or groups of ingredients elicit anti-tumor activities. By now, the active components reported to have the anti-tumor effects are ursolic acid and flavonoids, which shall be discussed in the following context respectively.

Ursolic acid, a triterpenoid which is distributed widely in the medicinal plants, is also the dominant compound in P. vulgaris with many bioactivities including hepatoprotection and anti-cancer [86]. The content of ursolic acid is used as the referential criteria of controlling the quality of $P$. vulgaris by Chinese Pharmacopoeia. The contents of ursolic acids in $P$. vulgaris flowers, stems and leaves harvested in June are $0.5110 \%, 0.3046 \%$ and $0.9364 \%$, respectively. But in July, the content ursolic acids in P. vulgaris cob, stems and leaves changed to $0.7800 \%, 0.4356 \%$ and $0.6788 \%$, respectively [87]. Ursolic acid has been listed as one of the most promising cancer chemoprevention drugs in 1990 [88]. In recent years, studies indicated that ursolic acid might prevent mutations induced by carcinogens, such as benzopyrene[B $(\alpha) \mathrm{P}$ ] and aflatoxin $\mathrm{B}$ [89] [90], inhibit tumor promotion of phorbol ester (TPA) in mouse skin cancer induced by 2-methyl-benzo onion (DMBA) [91]. Apart from anti-mutation and anti-tumor promotion activities, the initial anti-mutation and anti-tumorpromotin activities of ursolic acid might act through its anti-oxidative effect, in which both the carcinogen-inducing and cancer promoting stages are connected with active oxygen. The carcinogens could have been activated as an extremely reactive electrophillic compounds or free radicals before carcinogenesis occurred, which could damage the target molecules by the interaction with them and then result in the expression of cancer gene [92]. Ursolic acid could capture $\mathrm{O}_{2}^{-}$and show strong inhibition to lipid peroxidations in the liver microsomes and the $\mathrm{P}_{450}$ 
monoamine oxidase system [93]. Ursolic acid could inhibit the activity of cyclooxygenase-2 $(\mathrm{COX}-2)\left(\mathrm{IC} \mathrm{50}_{50}\right.$ $130 \mu \mathrm{M})$ so strongly that it could be used as antioxidant, protecting DNA molecules from being oxidative attack [94] [95]. Cytotoxicity tests against six kinds of cancer cell lines with ursolic acid had shown that it has obvious cytotoxicity against P388, leukemia cells (L1210 and L1810) and human adenocarcinoma cells lung cancer A549 (ED $50<4 \mathrm{mg} / \mathrm{L})$ as well as S180 cell [96]. The anti-neoplatic activity of ursolic acid might be associated with the induction of cancer cell differentiation [97] [98]. Neovascularization is an important step in the growth and metastasis of tumors [99], ursolic acid is a strong inhibitor of angiogenesis [92] [100] [101]. The proliferation of genomic DNA induced by ursolic acid indicated that the mechanism for inducing death of the cells should be apoptosis [102]. Ursolic acid could inhibit the proliferation and induce apoptosis of human acute promyelocytic leukemia cells (HL-60) [103]. In summary, anti-mutagenic, anti-carcinogenic, anti-proliferative, anti-angiogeneic and anti-oxidative effects have made ursolic acid the focus for developing a new clinical anticancer agent.

Flavonoids, a group of natural polyphenolic compounds, have been researched for their anti-oxidative and anti-neoplastic activity ever since the 1970's [104] [105]. The anti-cancer activity of flavonoids might be connected with the following five aspects:

1) Flavonoids could inhibit proliferation of cells mainly by stopping cell cycle with cytotoxic effect to cancer cells [106]-[108] and without toxicity or mutagenic effects to normal cells [109]. Flanonoids also showed anti-oxidative activity [110] [111] and positive immune regulation function [112].

2) Flavonoids could promote the apoptosis of tumor cells. The cell viability test had confirmed that Licochalcone-A could not only inhibit the growth of both human breast cancer cells MCF-7 and human leukemia cells HL-60, but also strengthen the effect of vincristine by inducing the apoptosis of the above two cell lines through down-regulation of the expression of anti-apoptotic protein bcl-2 and the ratio of bcl-2/bax complex [113]. The above apoptosis-inducing properties of flavonoids have been confirmed by other research [114]-[117].

3) Flavonoids could inhibit the activity of tyrosine protein kinase (TPK), protein kinase C, and phosphatidylinositol 3-kinase (PI3) during the process of cell signal transduction [118]-[121]. Sharing structural similarity and weak estrogen-like effect with estrogens, flavonoids are also known as phytoestrogens, which have been confirmed as inhibitors of TPK with cytotoxic and inhibitory effect against a variety of hormone-dependent noeplasms [122].

4) Flavonoids could promote the expression of anti-oncogenes and inhibit the expression of oncogenes [123].

5) Flavonoids could also prevent tumor growth by inhibiting the formation of new blood vessel in solid tumors and irreversibly inhibiting the blood supply of tumor [124].

There are many kinds of anti-neoplastic chemical compositions in $P$. vulgaris, including ursolic acid and flavonoids, polysaccharides and coumarins, that it is quite worthwhile to research this herb further and develop new anti-cancer drugs.

\subsection{Other Biological Functions}

The pharmacological research showed that $P$. vulgaris decoction at 1:100, 1:50 and 1:25 dilutions could strengthen the intestinal peristalsis of isolated rabbits. $P$. vulgaris decoction at 1:200, 1:100 and 1:50 might cause the tetanic contraction of the isolated uterine of the domestic rabbits. P. vulgaris decoction at $50 \%$ and $100 \%$ could obviously show vasodilative effect in the perfusion experiment on the lower limbs of toads [1].

The immediate-type anti-allergic activity of aqueous extract of $P$. vulgaris (Labiatae) (PVAE) was reported [125] [126]. In this report, $P$. vulgaris increased lymphocytes and leucocytes and inhibited the release of allergic media to have an anti-histamine effect. The protection against myocardial ischemia-reperfusion by $P$. vulgaris extract composition was also reported [125]. The anti-phage and anti-tussive activities of P. vulgaris are often used in the treatment of cough with chest pain and hemoptysis, combined with other traditional Chinese medicine, such as Pyrrosia lingus, Peucedanum praeruptorum and Taraxacum officinale Dandelion. Besides, P. vulgaris has been reported to treat headache, irritability, moss yellow and pulse string in Chinese traditional medicine.

\section{Conclusion}

As a summary, $P$. vulgaris is widely distributed all over the world, with rich sources and relative cheap price. It has so many kinds of active constituents that researching and developing this species for further potential medical 
usage are worthwhile and fruitful. It is quite important to mention that the anti-neoplastic activity of this species has become the focus of research. The mechanism for its anti-neoplatic activity has been researched and discussed deeply at the molecular level, which includes from the anti-neoplastic spectrum of $P$. vulgaris in vitro, the isolation and identification of anti-cancer active constituents, toxicology research and the establishment of the targets and dosage of drugs for cancer treatment. Hopefully, P. vulgaris will continue to be a source for developing new anti-neoplastic drugs.

\section{Acknowledgements}

The authors would like to thank the Chinese Medicinal Burro in Shaan Xi Province of China for financial funding with the title of Antineoplastic active chemical substance in P. vulgaris L. (Registration number is 2009zy54), the Scientific Research Foundation for the Returned Overseas Chinese Scholars, State Education Ministry, China (2011), the Shaanxi Province Science and Technology Research and Development Program of China, International Cooperation (2013KW31-04) and the National Natural Science Foundation of China (Grants 81172957) for the financial support.

\section{References}

[1] Liu, Y., Song, S.J. and Xu, S.X. (2003) Advances in the Study on the Chemical Constituents and Biological Activities of Prunella vulgaris L. Shenyang Yike Daxue Xuebao, 20, 55-59.

[2] Qin, J.H. (2008) Preparation of Prunella Vulgaris Extract Composition Used in Medicine. CN Patent No. 101274012 A.

[3] Psotova, J., Svobodova, A., Kolarova, H. and Walterova, D. (2006) Photoprotective Properties of Prunella vulgaris and Rosmarinic Acid on Human Keratinocytes. Journal of Photochemistry and Photobiology B: Biology, 84, 167-174. http://dx.doi.org/10.1016/j.jphotobiol.2006.02.012

[4] Cheng, H.Y. and Zhang, Q.F. (2008) Enhanced Analysis of Triterpenes, Flavonoids and Phenolic Compounds in Prunella vulgaris L. by Capillary Zone Electrophoresis with the Addition of Running Buffer Modifiers. Journal of Chromatography A, 1213, 231-238. http://dx.doi.org/10.1016/j.chroma.2008.10.033

[5] Sun, W.G., Liao, H.L., Ye, Z.M. and He, G.X. (2003) Chemical and Pharmacological Studies Overview of Prunella vulgari. Zhongguo Zhongyiyao Xinxi Zazhi, 10, 86-88.

[6] Wang, Z.J., Zhao, Y.Y., Chen, Y.Y., et al. (2000) Triterpenoid Compounds of Prunella Genus and Their Features of ${ }^{13} \mathrm{C}$ NMR Spectroscopy. Chinese Materia Medica, 25, 583-588.

[7] Cai, Z.Q., Ma, H.Y. and Zhang, M. (2009) Content Analysis of Oleanolic Acid and Ursolic Acid in Prunella vulgaris Based on Its Provenances and Appearances. Guangdong Yaoxueyuan Xuebao, 25, 256-258.

[8] Sun, Y.M., Xu, J.Z., Wang, Z.A. and Yu, X.P. (2009) Determination of Ursolic Acid in Prunella vulgaris from Different Areas by HPLC. Shizhen Guoyi Guoyao, 20, 1125-1126.

[9] Kojima, H. and Ogura, H. (1986) Triterpenoids from Prunella vulgaris. Phytochemistry, 25, 729-729. http://dx.doi.org/10.1016/0031-9422(86)88033-5

[10] Kojima, H., Tominaga, H., Sato, S., Ogura, H., et al. (1987) Pentacyclic Triterpenoids from Prunella vulgaris. Phytochemistry, 26, 1107-1111. http://dx.doi.org/10.1016/S0031-9422(00)82359-6

[11] Kojima, H., Tominaga, H. and Sato, S. (1988) Two Novel Hexacyclic Triterpenoids from Prunella vulgaris. Phytochemistry, 27, 2921-2925. http://dx.doi.org/10.1016/0031-9422(88)80689-7

[12] Ryu, S.Y., Oak, M.H., Yoon, S.-K., Cho, D.-I., Yoo, G.-S., Kim, T.-S. and Kim, K.-M. (2000) Anti-Allergic and AntiInflammatory Triterpenes from the Herb of Prunella vulgaris. Planta Medica, 66, 358-360. http://dx.doi.org/10.1055/s-2000-8531

[13] Gai, C.Y., Kong, D.Y., Wang, S.G., et al. (2010) Study on Chemical Constituents of Prunella vulgaris L. Chinese Journal of Pharm, 41, 8580-8582.

[14] Zhang, L.Z., Guo, Y.J., Tu, G.Z., et al. (2008) A Novel Triterpenoid Saponin from Prunella vulgaris. Yaoxue Xuebao, 43, 169-172.

[15] Lee, I.K., Kim, D.H., Lee, S.Y., Kim, K.R., Choi, S.U., Hong, J.K., Lee, J.H., Hyun, L.J. and Hyun, P.Y. and Ro, L.K. (2008) Triterpenoic Acids of Prunella vulgaris var. lilacina and Their Cytotoxic Activities in Vitro. Archives of Pharmacal Research, 31, 1578-1583. http://dx.doi.org/10.1007/s12272-001-2154-6

[16] Zhang, J.Y. and Yang, C.R. (1995) The Two New Ursane Glycosides from Prunella vulgaris in France. Yunnan Zhiwu Yanjiu, 17, 468-472. 
[17] Wang, Z.J., Zhao, Y.Y., Tu, G.Z., Hong, S.L. and Chen, Y.Y. (1999) Studies on Chemical Constituents from Prunella vulgaris. Нuaxue Xuebao, 34, 679-681.

[18] Hisashi, K., Noriko, S., Akiko, H. and Haruo, O. (1990) Constituents of the Labiatae Plants Part 5. Sterol Glucosides from Prunella vulgaris. Phytochemistry, 29, 2351-2355. http://dx.doi.org/10.1016/0031-9422(90)83073-A

[19] Meng, Z.M. and He, L.W. (1995) Studies on Constituent of Prunella vulgaris L. Zhongguo Yaoke Daxue Xuebao, 26, 329-331.

[20] Liu, B., Ma, G.P. and Shi, R.B. (2002) The Determination of Cyasterone in Prunella vulgaris L Var. Leucantha Schur Sec. Bailey Using RP-HPLC. Chinese Traditional and Herbal Drugs, 33, 898-899.

[21] Tian, J., Xiao, Y.Y., Zhao, Y.Y., et al. (2000) Structure Identification of New Compound Vulgarsaponin a from Prunella vulgaris. Yaoxue Хuebao, 35, 29-31.

[22] Psotova, J., Chlopcikova, S., Miketova, P. and Šimánek, V. (2005) Cytoprotectivity of Prunella vulgaris on Doxorubicin-Treated Rat Cardiomyocytes. Fitoterapia, 76, 556-561. http://dx.doi.org/10.1016/j.fitote.2005.04.019

[23] Zhu, J.U., Wang, Z.J., Zhao, Y.Y., et al. (2001) Depsides from Prunella vulgaris. Zhongguo Shiyan Fangjixue Zazhi, S1, 157-161.

[24] Hu, X., Cui, S., Chen, X. and Hu, Z.D. (2009) CE with Field-Enhanced Stacking for Rapid and Sensitive Determination of Umbelliferone, Rutin and Aesculetin in Prunella vulgaris. Chromatographia, 70, 1733-1736. http://dx.doi.org/10.1365/s10337-009-1373-8

[25] Jozef, S. (1963) Phytochemical Studies on Prunella vulgaris and Prunella Grandiflora Saponin and Triterpene Compounds. Dissertations Pharm, 15, 333-333.

[26] Dmitruk, I.S., Dmitruk, S.E., Berezovskaya, T.P., et al. (1987) Flavonoids of Vulgaris. Khimiya Prirodnykh Soedinenii, 3, 449-449.

[27] Dmitruk, I.S. (1987) Coumarins of Prunella vulgaris. Khimiya Prirodnykh Soedinenii, 4, 510-510.

[28] Yang, L.J., Li, Z.Q., Pu, F., et al. (1988) The Chemical Composition of the Essential Oil of Prunella vulgaris Liun. Yaowu Fenxi Zazhi, 8, 264-265.

[29] Wang, H.B., Zhang, Z.Y. and Su, Z.W. (1994) The Constituents of the Essential Oil from Three Plants of Prunella vulgari. Zhongguo Yaoxue Zazhi, 29, 652-653.

[30] Xu, Z.X., Zhou, Q.Q. and Xu, S.L. (1996) Recent Research Progress on Chemical Constituents and Biological Activities of Prunella vulgaris. Zhongchengyao, 18, 42-42.

[31] Tabba, H.D., Chang, R.S. and Smith, K.M. (1989) Isolation, Purification and Partial Characterization of Prunellin, an Anti-HIV Component from Aqueous Extracts of Prunella vulgaris. Antiviral Research, 11, 263-273. http://dx.doi.org/10.1016/0166-3542(89)90036-3

[32] Natherova, L., Leifertora, I. and Kunetkova, M. (1973) Evaluation of Flavonoids in the Domestic Specices of Genus Fragaria L. Ceskoslovenská Farmacie, 22, 441-443.

[33] Feng, Y., Xue, M., Jiang, L.H., et al. (2008) Chemical Study on Water Soluble Polysaccharides from Prunella vulgaris L. Zhongguo Yiyuan Yaoxue Zazhi, 28, 431-434.

[34] Rasool, R., Ganai, B.A., Akbar, S., Kamili, A.N. and Masood, A. (2010) Phytochemical Screening of Prunella vulgaris L.-An Important Medicinal Plant of Kashmir. Pakistan Journal of Pharmaceutical Sciences, 23, 399-402.

[35] Wang, Q.X. (1998) Treatment of Hypertension by the Effective Remedy. Shizhen Guoyi Guoyao, 9, 342-343.

[36] Jia, C.C., Wang, X.J. and Luan, Y.Y. (1999) External Usage of Traditional Chinese Medicine in the Treatment of Hypertension. Zhongguo Minjian Liaofa, 7, 14-15.

[37] He, Y.Q., Li, R.Z., Feng, L.Z. and Li, Z.P. (1985) Studies on the Chemical Constituents of Prunella vulgaris (I). Beijing Yika Daxue Xuebao, 17, 297-299.

[38] Li, Y.H., Niu, X. and Li, Y.G. (1996) Research on the Antihypertensive Activity of Sancaojiangyatang. Beijing Zhongyiyao Daxue Xиebao, 19, 45-46.

[39] Wang, H.B., Zhang, Z.Y., Su, Z.W., et al. (1994) On the Effect of Total Saponins from Common Selfheal (Prunell vulgaris) on Experimental Myocardial Infarction and Hypertension of Anesthetized Rats. Chinese Traditional and Herbal Drugs, 25, 302-303.

[40] Feng, P.F., Qin, N.P., Fang, R.Y., et al. (1998) Effect of Sanwu Hypertensive Decoction on Blood Pressure and Lymphokine-Activated Killer Cell in SHR. Zhongguo Xunhuan Zazhi, 13, 178-180.

[41] Panza, J.A., Carcia, C.E., Kileoyne, C.M., Quyyumi, A.A. and Cannon III, R.O. (1995) Impaired Endochelium Dependent Vasodilation in Patients with EH Evidence that Nitric Oxide Abnormality Is Not Localized to a Angle Aignal Transduction Pathway. Circulation, 91, 1732-1738. http://dx.doi.org/10.1161/01.CIR.91.6.1732 
[42] Kurmar, K.V. and Das, U.N. (1993) Are Free Radical Involved in the Pathobiology of Human Essential Hypertension. Free Radical Research, 19, 59-66. http://dx.doi.org/10.3109/10715769309056499

[43] Chen, W.H. and He, J.Y. (1997) Antagonistic Effects of Ephedra Sinica, Prunlla vulgaris and Cuttlefish Bone on the Model of Rat Acute Blood Stasis. Beijing Zhongyiyao Daxue Xuebao, 20, 39-41.

[44] Liu, J.X., Qin, Y.J. and Zhang, J.Y. (1998) Experimental Study on Treatment of Endometriorsis in Rabbit Model with the Method of Removing Blood Stasis and Resolving Phlegm, Softening and Resolving the Lump. Shangdong Zhongyiyao Daxue Xuebao, 22, 227-229.

[45] Li, S.C., Fan, J.F., Li, S.P., et al. (2001) Observation on Curative Effects of Supplemented Rhizoma Polygonati Sicao Decoction on the Patients with Ischemic Brain Damage. Zhongguo Zhongxiyi Jijiu Zazhi, 8, 376-377.

[46] Liang, X.L. (1998) Study on the Effect of the Model with Antilipidemic Activity with Sian Capsule. Chengdu Zhongyiiyao Daxue Xuebao, 21, 39-41.

[47] Psotova, J., Kolar, M., Sousek, J., Švagera, Z., Vičar, J. and Ulrichová, J. (2003) Biological Activities of Prunella vulgaris Extract. Phytotherapy Research, 17, 1082-1087. http://dx.doi.org/10.1002/ptr.1324

[48] Wang, Z.J., Zhao, Y.Y., Chen, Y.Y., et al. (2001) Chemical Constituents and Pharmacological Activities of Prunella Genus. World Phytomedicines, 16, 7-9.

[49] Zheng, M. (1990) Experimental Study of 472 Herbs with Antiviral Action against the Herpes Simplex Virus. Zhongxiyi Jiehe Zazhi, 10, 39-41.

[50] Zheng, M.S. and Li, W. (1991) Experimental Investigation into Antiviral Action of Prunella vulgaris L. on Type I Herpes Simplex Virus. Jiangxi Yixueyuan Xuebao, 31, 15-17.

[51] Chen, Q., Ceng, Y.G. and Cao, M.C. (2002) Research on the Analgesic and Anti-Inflammatory Activity of the Oral Drench Made from Prunella Vulgaries L. Jiceng Zhongyao Zazhi, 16, 6-7.

[52] Tang, C.K., Chen, G.J., Shen, Y.Q., et al. (1999) The Antipyretic and Anti-Inflammatory Activity of the Pills Made from Prunella vulgarites L. Zhongguo Shiyan Fangjixue Zazhi, 5, 54-55.

[53] Xiao, L.Y. and Huang, C.P. (2001) A Discussion on Sensitivity of 23 Chinese Herbage Medicines against MRSA. Shizhen Guoyi Guoyao, 12, 878-879.

[54] Zhang, F.X., Deng, W.D., Hu, Y.J. and Wu, X.X. (1999) Inhibitory Effect of Aikeqing on the Activity of Immunodeficiency Virus of Simian in Vitro. Guangzhou Zhongyiyao Daxue Xuebao, 16, 127-129.

[55] Fang, X.Y., Chang, R.C.C., Yuen, W.H. and Zee, S.Y. (2005) Immune Modulatory Effects of Prunella vulgaris L. International Journal of Molecular Medicine, 15, 491-496.

[56] Xu, H.X., Lee, S.H.S., Lee, S.F., White, R.L. and Blay, J. (1999) Isolation and Characterization of an Anti-HSV Polysaccharide from Prunella vulgaris. Antiviral Research, 44, 43-54. http://dx.doi.org/10.1016/S0166-3542(99)00053-4

[57] Lam, T.L., Lam, M.L., Au, T.K., Ip, D.T.M., Ng, T.B., Fong, W.P. and Wan, D.C.C. (2000) A Comparison of Human Immunodeficiency Virus Type-1 Protease Inhibition Activities by the Aqueous and Methanol Extracts of Chinese Medicinal Herbs. Life Sciences, 67, 2889-2896. http://dx.doi.org/10.1016/S0024-3205(00)00864-X

[58] Kageyama, S., Kurokawa, M. and Shiraki, K. (2000) Extract of Prunella vulgaris Spikes Inhibits HIV Replication at Reverse Transcription in Vitro and Can Be Absorbed from Intestine in Vivo. Antiviral Chemistry \& Chemotherapy, 11, 157-164.

[59] Yamasaki, K., Nakano, M., Kawahata, T., Mori, H., Otake, T., Ueba, N., Oishi, I., Inami, R., Yamne, M., Nkamura, M., Murata, H. and Naknishi, T. (1998) Anti-HIV-1 Activity of Herbs in Labiatae. Biological \& Pharmaceutical Bulletin, 21, 829-833. http://dx.doi.org/10.1248/bpb.21.829

[60] Yamasaki, K., Otake, T., Mori, H., Morimoto, M., Ueba, N., Kurokawa, Y., Shiota, K. and Yuge, T. (1993) Screening Test of Crude Drug Extract on Anti-HIV Activity. Yakugaku Zasshi: Journal of the Pharmaceutical Society of Japan, 113, 818-824.

[61] Au, T., Lam, T., Ng, T., Fong, W. and Wan, D. (2001) A Comparison of HIV-1 Integrase Inhibition by Aqueous and Methanol Extracts of Chinese Medicinal Herbs. Life Sciences, 68, 1687-1694. http://dx.doi.org/10.1016/S0024-3205(01)00945-6

[62] Zheng, M.S. and Zhang, Y.Z. (1990) Anti-HBsAg Herbs Employing ELISA Technique. Zhongxiyi Jihe Zazhi, 10, 560562.

[63] Zheng, J., He, J.G., Ji, B.P., Li, Y. and Zhang, X.F. (2007) Antihyperglycemic Activity of Prunella vulgaris L. in Streptozotocin-I Nduced Diabetic Mice. Asia Pacific Journal of Clinical Nutrition, 16, 427-431.

[64] Huang, N., Hauck, C., Yum, M.Y., Rizshsky, L., Widrlechner, M.P., Mccoy, J.A., Murphy, P.A., Dixon, P.M., Nikolau, B.J. and Birt, D.F. (2009) Rosmarinic Acid in Prunella vulgaris Ethanol Extract Inhibits Lipopolysaccharide-Induced Prostaglandin E2 and Nitric Oxide in RAW 264.7 Mouse Macrophages. Journal of Agricultural and Food Chemistry, 
57, 10579-10589. http://dx.doi.org/10.1021/jf9023728

[65] Zdařilová, A., Svobodová, A., Šimánek, V. and Ulrichová, J. (2009) Prunella vulgaris Extract and Rosmarinic Acid Suppress Lipopolysaccharide-Induced Alteration in Human Gingival Fibroblasts. Toxicology in Vitro, 23, 386-392. http://dx.doi.org/10.1016/j.tiv.2008.12.021

[66] Jung, Y.B., Roh, K.J., Jung, J.A., Jung, K., Yoo, H., Cho, Y.B., Kwak, W.J., Kim, D.K., Kim, K.H. and Han, C.K. (2001) Effect of SKI 306X, a New Herbal Anti-Arthritic Agent, in Patients with Osteoarthritis of the Knee: A DoubleBlind Placebo Controlled Study. The American Journal of Chinese Medicine, 29, 485-491. http://dx.doi.org/10.1142/S0192415X01000502

[67] Choi, J.H., Kim, D.Y., Yoon, J.H., Youn, H.Y., Yi, J., Rhee, H.I., Ryu, K., Jung, K. and Han, C.K. (2002) Effects of SKI 306X, a New Herbal Agent, on Proteoglycan Degradation in Cartilage Explant Culture and Collagenase-Induced Rabbit Osteoarthritis Model. Osteoarthritis and Cartilage, 10, 471-478. http://dx.doi.org/10.1053/joca.2002.0526

[68] Jiang, Y., Jun, J.H. and Sun, X.Y. (1988) The Effect of Prunella vulgaris L on the Thymus, Spleen and Adrenalin of Animal. Gansu Yiyao, 7, 4-7.

[69] Fang, X., Yu, M.M.S., Yuen, W.H., Zee, S.Y. and Chang, R.C. (2005) Immune Modulatory Effects of Prunella vulgaris L. on Monocytes/Macrophages. International Journal of Molecular Medicine, 16, 1109-1116.

[70] Ma, D.E., Wang, Z.M. and Ma, A.Y. (1983) The Anti-Inflammatory Activity and the Effect on the Immune Organs of Prunella vulgaris. Shanxi Yiyao Zazhi, 12, 4-7.

[71] Xu, L.S. (1989) Pharmacological Research on the Hypoglycemic Effect of the Active Ingredienst in Prunella vulgaris. Chinese Traditional and Herbal Drugs, 20, 22-24.

[72] Liu, B.L., Zhu, D.N. and Wang, G. (1995) Effects of the Alcohol Extract of Spica Pranellae on Bloodglucose in Mice. Zhongguo Yaoke Daxue Xuebao, 26, 44-46.

[73] Feng, M.L., Jia, L.L., Wu, Y.P., et al. (2000) Effect of the Alcoholic Extraction of Spica Prunellae on Experimental Diabetic Nephropathy. Shanxi Zhongyi Xueyuan Xuebao, 1, 7-9.

[74] Wang, J.G. (2001) Liver-Protective Effect of Prunella vulgaris Mixture. Chinese Traditional and Herb Drugs, 32, 625-627.

[75] Zhang, J. and Tao, X.P. (2000) the Effect of Prunella vulgaris on Liver Fibrosis Indexes. Jiceng Zhongyao Zazhi, 14, 60-60.

[76] Meng, G., Zhang, K.J. and Zhang, M.Z. (2007) Chemical Constituents of Prunella vulgaris L and Antitumor Activity. Northwest Pharmaceutical Journal, 22, 211-213.

[77] Liu, L., Xu, D.S., Zhou, R.Y. and Zhong, Y. (2008) Effective Fraction of Prunella Vulgaris and Its Application in Preparation of Medicines for Treating Colon Cancer. CN Patent No. 101317883 A.

[78] Wang, K., Dong, H.F., Zhang, X.Y., et al. (2000) The Effect of Prunella vulgaris L on SGC-7901 Cells. Shanghai Yixue Jianyan Zazhi, 15, 305-306.

[79] Lee, K.H., Lin, Y.M., Wu, T.S., Zhang, D.C., Yamagishi, T., Hayashi, T., Hall, I.H., Chang, J.J., Wu, R.Y. and Yang, T.H. (1988) The Cytotoxic Principles of Prunella vulgaris, Psychotria serpens, and Hyptis capitata: Ursolic Acid and Related Derivatives. Planta Medica, 54, 308-311. http://dx.doi.org/10.1055/s-2006-962441

[80] Xu, Z.W., Zhou, R.Y., Wang, W.H., et al. (2001) Mechanism Study of "Prunella Injection” on Formation of Pleural Fibrosis. Zhejiang Zhongxiyi Jiehe Zazhi, 11, 5-8.

[81] Zhou, R.Y., Xu, Z.W. and Ni, A.D. (2001) Clinical and Experimental Observations of Hydrothorax in Lung Cancer Cases Treated with Closed Drainage and Injection of Selfheal Spike Injection. Shanghai Daxue Xuebao, 15, 49-51.

[82] Chen, C.Y., Wu, G. and Zhang, M.Z. (2009) The Effects and Mechanism of Action of Prunella vulgaris L Extract on Jurkat Human T Lymphoma Cell Proliferation. Chinese-German Journal of Clinical Oncology, 8, 426-429.

[83] Zhang, M.Z. and Liu, H.M. (2009) Method for Extracting Anti-Tumor Effective Parts from Chinese Medicine Prunella. CN Patent No. 101461842 A.

[84] Lee, H. and Lin, J.Y. (1988) Antimutagenic Activity of Extracts from Anticancer Drugs in Chinese Medicine. Mutation Research/Genetic Toxicology, 204, 229-234.

[85] Lamaison, J., Petitjean-Freytet, C. and Carnat, A. (1990) Medicinal Lamiaceae with Antioxidant Properties, a Potential Source of Rosmarinic Acid. Pharmaceutica Acta Helvetiae, 66, 185-188.

[86] Liu, J. (2005) Oleanolic Acid and Ursolic Acid: Research Perspectives. Journal of Ethnopharmacology, 100, 92-94. http://dx.doi.org/10.1016/j.jep.2005.05.024

[87] Wang, H.B., Zhang, Z.Y., Zai, Z.X., Su, Z. and Li, C.K. (1993) Qualitative Analysis of Chinese Drug Xiakucao (Prunella). Zhongguo Zhongyao Zazhi, 18, 655-657.

[88] Muto, Y., Ninomiya, M. and Fujiki, H. (1990) Present Status of Research on Cancer Chemoprevention in Japan. Japa- 
nese Journal of Clinical Oncology, 20, 219-224.

[89] Niikawa, M., Hayashi, H., Sato, T., Nagase, H. and Kito, H. (1993) Isolation of Substances from Glossy Privet (Ligustrum lucidum Ait.) Inhibiting the Mutagenicity of Benzo[A]Pyrene in Bacteria. Mutation Research/Genetic Toxicology, 319, 1-9.

[90] Young, H., Chung, H., Lee, C., Park, K., Yokozawa, T. and Oura, H. (1994) Ursolic Acid Inhibits Aflatoxin B ${ }_{1}$-Induced Mutagenicity in a Salmonella Assay System. Biological \& Pharmaceutical Bulletin, 17, 990-992. http://dx.doi.org/10.1248/bpb.17.990

[91] Huang, M.T., Ho, C.T., Wang, Z.Y., Ferraro, T., Lou, Y.R., Stauber, K., Ma, W., Georgiadis, C., Laskin, J.D. and Conney, A.H. (1994) Inhibition of Skin Tumorigenesis by Rosemary and Its Constituents Carnosol and Ursolic Acid. Cancer Research, 54, 701-708.

[92] Wang, J.J., Wang, B., Guo, J., Gao, Y., Xu, Q. and Chen, W.S. (2000) Inhibitory Effect of Ursolic Acid on Angiogenesis in Vitro. Academic Journal of Second Military Medical University, 21, 1071-1073.

[93] Balanehru, S. and Nagarajan, B. (1991) Protective Effect of Oleanolic Acid and Ursolic Acid against Lipid Peroxidation. Biochemistry International, 24, 981-990.

[94] Ringbom, T., Segura, L., Noreen, Y., Perera, P. and Bohlin, L. (1998) Ursolic Acid from Plantago Major, a Selective Inhibitor of Cyclooxygenase-2 Catalyzed Prostaglandin Biosynthesis. Journal of Natural Products, 61, 1212-1215. http://dx.doi.org/10.1021/np980088i

[95] Subbaramaiah, K., Michaluart, P., Sporn, M.B. and Dannenberg, A.J. (2000) Ursolic Acid Inhibits Cyclooxygenase-2 Transcription in Human Mammary Epithelial Cells. Cancer Research, 60, 2399-2404.

[96] Zhao, G.Q. (1996) Antineoplastic Activity of Ursolic Acid in Loquat Leaves Guowai Yiyao. Zhiwuxue Fence, 11, 180-180.

[97] Lee, H.Y., Chung, H.Y., Kim, K.H., Lee, J.J. and Kim, K.W. (1994) Induction of Differentiation in the Cultured F9 Teratocarcinoma Stem Cells by Triterpene Acids. Journal of Cancer Research and Clinical Oncology, 120, 513-518. http://dx.doi.org/10.1007/BF01221027

[98] Paik, K.J., Jeon, S.S., Chung, H.Y., Lee, K.H., Kim, K.W., Chung, J.K. and Kim, N.D. (1998) Induction of Differentiation of the Cultured Rat Mammary Epithelial Cells by Triterpene Acids. Archives of Pharmacal Research, 21, 398-405. http://dx.doi.org/10.1007/BF02974633

[99] Hanahan, D., Christofori, G., Naik, P. and Arbeit, J. (1996) Transgenic Mouse Models of Tumour Angiogenesis: The Angiogenic Switch, Its Molecular Controls, and Prospects for Preclinical Therapeutic Models. European Journal of Cancer, 32, 2386-2393. http://dx.doi.org/10.1016/S0959-8049(96)00401-7

[100] Sohn, K.H., Lee, H.Y., Chung, H.Y., Young, H.S., Yi, S.Y. and Kim, K.W. (1995) Anti-Angiogenic Activity of Triterpene Acids. Cancer Letters, 94, 213-218. http://dx.doi.org/10.1016/0304-3835(95)03856-R

[101] Wang, B., Wang, J.J. and Xu, J. (2001) Inhibitory Effect of Ursolic Acid on Angiogenesis in Vitro. Zhongliu Fangzhi Zazhi, 8, 351-352.

[102] Baek, J.H., Lee, Y.S., Kang, C.M., Kim, J., Kwon, K.S., Son, H.C. and Kim, K.W. (1997) Intracellular Ca ${ }^{2+}$ Release $^{2}$ Mediates Ursolic Acid-Induced Apoptosis in Human Leukemic HL-60 Cells. International Journal of Cancer, 73, 725-728. http://dx.doi.org/10.1002/(SICI)1097-0215(19971127)73:5<725::AID-IJC19>3.0.CO;2-4

[103] Huang, J., Sun, Y., Lu, S.X., Su, T. and Jiao, S.C. (1999) Experimental Study on Apoptosis Induced by Ursolic Acid Isolated from Asparagus in HL260 Cells. Zhongguo Zhongxiyijiehe Zazhi, 19, 296-298.

[104] Xu, G.F., Zhao, X.L. and Zhao, L. (2000) Apoptosis Inducde by Flavonoids Extract of Wheat Germ in a Human Breast Cancer Cell Line. Yingyang Xuebao, 22, 43-46.

[105] Wang, C., Zhang, L.S. and He, T. (2002) Study on Antiproliferation Effects of Genistein in Vitro. Zhongguo Gonggong Weisheng, 18, 1056-1058.

[106] Trochon, V., Blot, E., Cymbalista, F., Engelmann, C., Tang, R.P., Thomaïdis, A., Vasse, M., Soria, J., Lu, H. and Soria, C. (2000) Apigenin Inhibits Endothelial-Cell Proliferation in $\mathrm{G}_{2} / \mathrm{M}$ Phase Whereas It Stimulates Smooth-Muscle Cells by Inhibiting P21 and P27 Expression. International Journal of Cancer, 85, 691-696. http://dx.doi.org/10.1002/(SICI)1097-0215(20000301)85:5<691::AID-IJC15>3.0.CO;2-Q

[107] Zi, X., Zhang, J., Agarwal, R. and Pollak, M. (2000) Silibinin Up-Regulates Insulin-Like Growth Factor-Binding Protein 3 Expression and Inhibits Proliferation of Androgen-Independent Prostate Cancer Cells. Cancer Research, 60, 5617-5620.

[108] Senderowicz, A.M. (1999) Flavopiridol: The First Cyclin-Dependent Kinase Inhibitor in Human Clinical Trials. Investigational New Drugs, 17, 313-320. http://dx.doi.org/10.1023/A:1006353008903

[109] Huynh, H.T. and Teel, R.W. (1999) Selective Induction of Apoptosis in Human Mammary Cancer Cells (MCF-7) by Pycnogenol. Anticancer Research, 20, 2417-2420. 
[110] Wu, B., Xu, G.F., Zhao, X.L. and Ren, X. (2001) Antioxidation of Flavones of Wheat Germ on Mammary Tulnor of Rats. Weisheng Yanjiu, 30, 215-217.

[111] Chen, J.W., Hu, T.X. and Zhu, D.Y. (2002) Study on Structure-Activity Relationship of Eleven Natural Flavonoids Scavenging Superoxide Anion. Zhongguo Yaoxue Zazhi, 37, 57-58.

[112] Zhang, R.Q. and Han, Z.K. (1994) The Effect of Flavonoids on the Immune Function and the Level of B-Endorphins in the Blood of Mouse. Zhongguo Mianyi Zazhi, 10, 91-92.

[113] Rafi, M.M., Rosen, R.T., Vassil, A., Ho, C.T., Zhang, H., Ghai, G., Lambert, G. and Dipaola, R.S. (1999) Modulation of Bcl-2 and Cytotoxicity by Licochalcone-A, a Novel Estrogenic Flavonoid. Anticancer Research, 20, 2653-2658.

[114] Mcvean, M., Xiao, H., Isobe, K.I. and Pelling, J.C. (2000) Increase in Wild-Type P53 Stability and Transactivational Activity by the Chemopreventive Agent Apigenin in Keratinocytes. Carcinogenesis, 21, 633-639. http://dx.doi.org/10.1093/carcin/21.4.633

[115] Chan, F.L., Choi, H., Chen, Z., Chan, P.S. and Huang, Y. (2000) Induction of Apoptosis in Prostate Cancer Cell Lines by a Flavonoid, Baicalin. Cancer Letters, 160, 219-228. http://dx.doi.org/10.1016/S0304-3835(00)00591-7

[116] Wenzel, U., Kuntz, S., Brendel, M.D. and Daniel, H. (2000) Dietary Flavone Is a Potent Apoptosis Inducer in Human Colon Carcinoma Cells. Cancer Research, 60, 3823-3831.

[117] Ogata, S., Miyake, Y., Yamamoto, K., Okumura, K. and Taguchi, H. (2000) Apoptosis Induced by the Flavonoid from Lemon Fruit (Citrus limon BURM. F.) and Its Metabolites in HL-60 Cells. Bioscience, Biotechnology, and Biochemistry, 64, 1075-1078. http://dx.doi.org/10.1271/bbb.64.1075

[118] Blankson, H., Grotterød, E. and Seglen, P. (2000) Prevention of Toxin-Induced Cytoskeletal Disruption and Apoptotic Liver Cell Death by the Grapefruit Flavonoid, Naringin. Cell Death \& Differentiation, 7, 739-746. http://dx.doi.org/10.1038/sj.cdd.4400705

[119] Jiang, C., Agarwal, R. and Lü, J. (2000) Anti-Angiogenic Potential of a Cancer Chemopreventive Flavonoid Antioxidant, Silymarin: Inhibition of Key Attributes of Vascular Endothelial Cells and Angiogenic Cytokine Secretion by Cancer Epithelial Cells. Biochemical and Biophysical Research Communications, 276, 371-378. http://dx.doi.org/10.1006/bbrc.2000.3474

[120] Ishiwa, J., Sato, T., Mimaki, Y., Sashida, Y., Yano, M. and Ito, A. (2000) A Citrus Flavonoid, Nobiletin, Suppresses Production and Gene Expression of Matrix Metalloproteinase 9/Gelatinase B in Rabbit Synovial Fibroblasts. The Journal of Rheumatology, 27, 20-25.

[121] Nakahata, N., Kyo, R., Kutsuwa, M. and Ohizumi, Y. (1999) Inhibition of Mitogen-Activated Protein Kinase Cascade by Baicalein, a Flavonoid of Natural Origin. Nippon Yakurigaku Zasshi, 114, 215-219. http://dx.doi.org/10.1254/fpj.114.supplement_215

[122] Zhou, J., Purna, M. and Steven, K. (1998) Soybean Components Inhibit the Growth of Human Prostate Cancer Cell Line Lncap in SCID Mice via Alteration in Cells Apoptosis, Angiogenesis and Proliferation. FASEB Journal, $18,3822$.

[123] Ranelletti, F.O., Maggiano, N., Serra, F.G., Ricci, R., Larocca, L.M., Lanza, P., Scambia, G., Fattorossi, A., Capelli, A. and Piantelli, M. (2000) Quercetin Inhibits P21-RAS Expression in Human Colon Cancer Cell Lines and in Primary Colorectal Tumors. International Journal of Cancer, 85, 438-445. http://dx.doi.org/10.1002/(SICI)1097-0215(20000201)85:3<438::AID-IJC22>3.0.CO;2-F

[124] Fotsis, T., Pepper, M., Adlercreutz, H., Hase, T., Montesano, R. and Schweigerer, L. (1995) Genistein, a Dietary Ingested Isoflavonoid, Inhibits Cell Proliferation and in Vitro Angiogenesis. The Journal of Nutrition, 125, 790S-797S.

[125] Shin, T.Y., Kim, Y.K. and Kim, H.M. (2001) Inhibition of Immediate-Type Allergic Reactions by Prunella vulgaris in a Murine Model. Immunopharmacology and Immunotoxicology, 23, 423-435. http://dx.doi.org/10.1081/IPH-100107341

[126] Kim, S.Y., Kim, S.H., Shin, H.Y., Lim, J.P., Chae, B.S., Park, J.S., Hong, S.G., Kim, M.S., Jo, D.G., Park, W.H. and Shin, T.Y. (2007) Effects of Prunella vulgaris on Mast Cell-Mediated Allergic Reaction and Inflammatory Cytokine Production. Experimental Biology and Medicine, 232, 921-926. 